\title{
ELECTROLYTE CHANGES RELATED TO MUSCLE PAIN AFTER RESISTANCE EXERCISES
}

\author{
ALTERAÇÕESELETROLITIICAS RELACIONADAS À DORMUSCULAR APÓS EXERCÍCIOS RESISTIDOS
}

ALTERACIONESELECTROLITICAS RELACIONADAS AL DOLORMUSCULARDESPUÉSDEEJERCICIOS RESISTIDOS

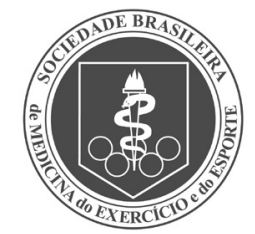

Original Article Artigo Original Artículo Original

\begin{abstract}
Kety Suelyn Ferreira' ${ }^{1}$ (iD) (Physiotherapist)

André de Oliveira Teixeira ${ }^{2}$ (ID) (Physical Education Professional)

Edineia de Brito' (ID)

(Physical Education Professional)

Bruno Cesar Correa Arbiza' (iD (Physiotherapist)

Gustavo Orione Puntel ${ }^{1}$ (ID

(Physiotherapist)

Antonio Marcos Vargas da Silva' (ID (Physiotherapist)

Felipe da Silva Paulitsch² (ID (Physician)

Luis Ulisses Signori' (DD

(Physiotherapist)

1. Universidade Federal de Santa Maria (UFSM), Santa Maria, RS, Brazil.

2. Universidade Federal do Rio Grande (FURG), Rio Grande do Sul, RS, Brazil.
\end{abstract}

\section{Correspondence:}

Luis Ulisses Signori

Universidade Federal de Santa Maria (UFSM), Postgraduate

Program in Physical-Functional Rehabilitation, Center for Health Sciences [Centro de Ciências da Saúde - CCS]. Av. Roraima, 1000, Camobi, Santa Maria, RS, Brazil. 97105-900.

I.signori@hotmail.com

\begin{abstract}
Introduction: Resistance exercises (RE) performed at high intensity cause an inflammatory response and electrolyte abnormalities in blood plasma. Objectives: To study the plasma electrolyte changes resulting from a high-intensity session of RE in untrained volunteers, and to correlate these with delayed onset muscle soreness (DOMS). Methods: Twenty volunteers, aged $26.9( \pm 4.4)$ years, underwent an RE session. The workout (leg extension, squat and leg press) consisted of four sets of 10 maximum repetitions. Electrolytes $\left(\mathrm{Na}^{+}, \mathrm{K}^{+}, \mathrm{Ca}^{2+} \mathrm{e} \mathrm{Mg}^{2+}\right)$ were evaluated before the training (baseline), immediately $(0$ min), and 30 minutes after the RE. The DOMS was assessed 24 hours after the sessions. Results: The $\mathrm{Na}^{+}$increased immediately after the RE and returned to normal after $30 \mathrm{~min}(\mathrm{p}<0.001)$. After $30 \mathrm{~min}, \mathrm{~K}^{+}$ increased compared to baseline levels and immediately after the RE $(p<0.001) . \mathrm{Ca}^{2+}$ and $\mathrm{Mg}^{2+}$ levels did not change throughout the study. Changes in $\mathrm{Na}^{+}$and $\mathrm{K}^{+}$levels were correlated immediately $(r=-0.511$; $p=0.021)$ and $30 \mathrm{~min}(r=-0.455 ; \mathrm{p}=0.049)$ after RE. Plasma concentrations of $\mathrm{Na}^{+} 0$ min were correlated $(r=-0.520 ; p=0.018)$ with the DOMS. Conclusion: High-intensity RE in untrained volunteers leads to changes in plasma concentrations of $\mathrm{Na}^{+}$and $\mathrm{K}^{+}$. $\mathrm{Na}^{+}$concentrations immediately after $\mathrm{RE}$ were related to DOMS; individuals that presented smaller alterations in this electrolyte reported more muscular pain. Level of evidence Il; Diagnostic Studies - Development of diagnostic criteria on consecutive patients (with universally applied reference "gold" standard).
\end{abstract}

Keywords: Exercise; Inflammation; Electrolytes; Myalgia.

\section{RESUMO}

Introdução: Os exercícios resistidos (ER) realizados em alta intensidade provocam uma resposta inflamatória e alterações eletrolíticas no plasma sanguíneo. Objetivo: Estudar as alterações eletrolíticas plasmáticas resultantes de uma sessão de ER de alta intensidade em voluntários destreinados e correlacionar com a dor muscular de início tardio (DMIT). Métodos: Vinte voluntários com 26,9 (₫4,4) anos de idade foram submetidos à sessão de ER. A sessão de exercícios (cadeira extensora, agachamento e leg press) consistiu em quatro séries de 10 repetições máximas. Os eletrólitos $\left(\mathrm{Na}^{+}, \mathrm{K}^{+}, \mathrm{Ca}^{2+} \mathrm{e} \mathrm{Mg}^{2+}\right.$ ) foram avaliados previamente (basal), imediatamente ( 0 min) e 30 minutos após os ER. A DMIT foi avaliada 24 horas após as sessões. Resultados: $\mathrm{O} \mathrm{Na}{ }^{+}$aumentou imediatamente após os ER e retornou ao normal após $30 \mathrm{~min}(p<0,001)$. Em $30 \mathrm{~min}$, o $\mathrm{K}^{+}$aumentou em relação aos valores basais e imediatamente após os $E R(p<0,001)$. O $\mathrm{Ca}^{2+}$ e o $\mathrm{Mg}^{2+}$ não se modificaram ao longo do estudo. As alterações de $\mathrm{Na}^{+}$e de $\mathrm{K}^{+}$correlacionaram-se imediatamente $(r=-0,511 ; p=0,021)$ e $30 \mathrm{~min}(r=-0,455 ; p=0,049)$ após os $E R$. As concentrações plasmáticas de $\mathrm{Na}^{+} 0$ min correlacionam-se ( $\left.r=-0,520 ; p=0,018\right)$ com a DMIT. Conclusão: Os ER de alta intensidade em voluntários destreinados aumentaram as concentrações plasmáticas de $\mathrm{Na}^{+}$e de $\mathrm{K}^{+}$. As concentrações de $\mathrm{Na}^{+}$imediatamente após os ER correlacionaram-se com a DMIT, em que os indivíduos que apresentam menores alterações desse eletrólito sentem mais dor muscular. Nível de Evidência ll; Estudos diagnósticos - Desenvolvimento de critérios diagnósticos em pacientes consecutivos (com padrão de referência "ouro" aplicado).

Descritores: Exercício; Inflamação; Eletrólitos; Mialgia.

\section{RESUMEN}

Introducción: Los ejercicios resistidos (ER) realizados en alta intensidad provocan una respuesta inflamatoria y alteraciones electrolíticas en el plasma sanguíneo. Objetivo: Estudiar las alteraciones electrolíticas plasmáticas resultantes de una sesión de ER de alta intensidad en voluntarios desentrenados y correlacionar con el dolor muscular de inicio tardío (DMIT). Métodos: Veinte voluntarios con 26,9 $( \pm 4,4)$ años de edad fueron sometidos a la sesión de ER. La sesión de ejercicios (mesa extensora, sentadillas y leg press) consistió en cuatro series de 10 repeticiones máximas. Los electrólitos $\left(\mathrm{Na}^{+}, \mathrm{K}^{+}, \mathrm{Ca}^{2+}\right.$ y $\left.\mathrm{Mg}^{2+}\right)$ fueron evaluados previamente (basal), inmediatamente (0 min) y 30 minutos después de los ER. La DMIT fue evaluada 24 horas después de las sesiones. Resultados: El $\mathrm{Na}^{+}$aumentó inmediatamente después de los ER y retornó a lo normal después de $30 \mathrm{~min}(p<0,001)$. En $30 \mathrm{~min}$ el $\mathrm{K}^{+}$aumentó con relación a los valores basales e inmediatamente después de los $E R(p<0,001)$. El $\mathrm{Ca}^{2+}$ y el $\mathrm{Mg}^{2+}$ no se modificaron a lo largo del estudio. Las alteraciones de $\mathrm{Na}^{+}$y de $\mathrm{K}^{+}$ se correlacionaron inmediatamente $(r=-0,511, p=0,021)$ y $30 \mathrm{~min}(r=-0,455, p=0,049)$ después de los ER. Las 
concentraciones plasmáticas de $\mathrm{Na}^{+} 0$ min se correlacionan ( $\left.r=-0,520, p=0,018\right)$ con la DMIT. Conclusión: Los ER de alta intensidad en voluntarios desentrenados aumentaron las concentraciones plasmáticas de $\mathrm{Na}^{+}$y de $\mathrm{K}^{+}$. Las concentraciones de $\mathrm{Na}^{+}$inmediatamente después de los ER se correlacionaron con la DMIT, en que los individuos que presentan menores alteraciones de ese electrolito sienten más dolor muscular. Nivel de evidencia Il; Estudios diagnósticos - Desarrollo de criterios diagnósticos en pacientes consecutivos (con estándar de referencia "oro" aplicado).

\section{Descriptores: Ejercicio; Inflamación; Electrólitos; Mialgia;}

\section{INTRODUÇÃO}

Resistance exercises (RE) are a type of physical activity aimed at increasing muscle strength and hypertrophy. ${ }^{1,2}$ The regular practice of these exercises improve athletic performance, promote health, prevent diseases and are part of the rehabilitation of patients. ${ }^{2,3}$ However, RE performed at high intensity causes an acute inflammatory response. ${ }^{4-6}$

Inflammatory process results from injury to muscle fibers ${ }^{7}$ due to an increased production of oxygen and nitrogen reactive species that induce oxidative stress. ${ }^{4,5}, \mathrm{After}$ RE, inflammatory cytokines are released into the blood, including interleukins (IL), tumor necrosis factor alpha $(\mathrm{TNFa})^{9}$ and acute phase proteins such as C-reactive protein (CRP)., ${ }^{4,5}$ Clinically, the inflammatory response is perceived by delayed onset muscle soreness (DOMS), that may occur after exercise, but usually occurs between 24 to 72 hours (h) after physical activity and can last for up to seven days. ${ }^{10,11}$ This response leads to decreased functionality and abandonment of exercise programs, especially in sedentary and / or untrained individuals. ${ }^{12}$

Electrolytes (cations and anions) are distributed in intracellular and extracellular fluid and blood plasma, which have the function of osmoregulation. ${ }^{13}$ The most commonly evaluated electrolytes are sodium $\left(\mathrm{Na}^{+}\right)$, potassium $\left(\mathrm{K}^{+}\right)$, calcium $\left(\mathrm{Ca}^{2+}\right)$ and magnesium $\left(\mathrm{Mg}^{2+}\right)$, and their alterations can generate electrolyte disturbances, which include dehydration, neuromuscular changes, paresthesias and muscle pain. ${ }^{13-15}$ The RE on these serum components are influenced by environmental conditions, exercise intensity and effort duration, ${ }^{16,17}$ because these factors influence dehydration, which reduces the amount of bioavailable electrolytes during exercise. ${ }^{18}$ In this context, electrolyte alterations after RE have been little studied yet, although these evaluations are extremely important to develop appropriate measures for rehydration and the possible prevention of discomfort after these exercises. The objectives of this research were to study the electrolytic changes of $\mathrm{Na}^{+}, \mathrm{K}^{+}, \mathrm{Ca}^{2+}$ and $\mathrm{Mg}^{2+}$ in untrained volunteers after resistance exercise (RE) and to analyze the influence of these changes on delayed onset muscle soreness.

\section{METHOD}

This cross-sectional study was approved by the Research Ethics Committee of the Federal University of Rio Grande (CEPAS, no 23116.002536/2010-48). The research follows the norms of Resolution $n^{\circ} 466 / 2012$ of the National Health Council and is in line with the Declaration of Helsinki (2013). All volunteers were previously evaluated by an attending physician, then informed about the procedures, data collection, and signed the Free Informed Consent Form.

\section{Eligibility Criteria}

The sample consisted of 20 volunteers. Inclusion criteria were ages between 20 and 35 years old, with body mass index (BMI) less than 30 $\mathrm{kg} / \mathrm{m}^{2}$, non-practitioners of physical activity and/or exercise regularly (more than once a week), that were not included in diet programs, as well as without previous diagnosis of musculoskeletal, rheumatologic, cardiovascular, metabolic, neurological, oncological, immunological or hematological diseases. Smokers and individuals who used any type of food, vitamin, and/or ergogenic supplement or medication were not included in the study. On the day of the exam, volunteers that presented inflammatory response (CRP $>3 \mathrm{mg} / \mathrm{dL}$; fibrinogen $<200$ and $>400$ $\mathrm{mg} / \mathrm{dL})$, blood glucose (>100 mg/dL), leukocytosis $\left(>11000 \times 10^{3} / \mathrm{mm}^{3}\right)$, systemic blood pressure (>140/90 mmHg) and/or any symptoms of pain and/or discomfort were excluded from the study. The consumption of alcoholic beverages and fruit juices, as well as physical activities were restricted for $72 \mathrm{~h}$ prior to data collection.

\section{Muscle strength evaluation}

The 10 maximal repetition test (10RM) was adopted for the performance of the training protocol with controlled overload. The selected exercises were the extensor bench, the squat and the leg press and performed in Physicus ${ }^{\circledast}$ equipment (Plus model, SP, Brazil). Recovery time between exercises was of 5 minutes (min). Values of the maximum loads in the 10RM test were obtained through 3 to 5 attempts, when the patient presented a concentric failure frame for the dynamic movement. At each new attempt, increments of $5 \mathrm{~kg}$ were added, with 3 to $4 \mathrm{~min}$ intervals between each series. Maximum load was validated according to what was obtained in the last execution. ${ }^{4-6}$

\section{Exercise session}

For each proposed exercise volunteers were submitted to specific warm-up exercise ( 1 series of 15 repetitions with $40 \%$ of the maximum load obtained in the 10RM test). The sequence of RE (extensor bench, squat and leg press) was randomized by draw-in closed brown envelope, and the exercise sessions were composed of 4 series of 10RM, with intervals of 1 min between sets and 2 min between exercises. During the evaluations and exercises, verbal stimuli were used to the volunteer. ${ }^{4-6}$

\section{Data collect}

The volunteers were fasting for $12 \mathrm{~h}$. Blood samples were collected before RE (baseline), immediately ( 0 min) and 30 min after the session. Twenty-four $h$ after the exercise session, the subjective perception of pain was assessed by the visual analogue scale. ${ }^{4}$

\section{Biochemical measurements}

Total cholesterol, triglycerides, high density lipoproteins (HDL), glucose, uric acid and urea were evaluated by commercial LAB TEST kits (Lagoa Santa, MG, Brazil) and analyzed by LAB MAX 240 (Tokio, Japão). Low density lipoproteins (LDL) were calculated using Friedewald's formula. Fibrinogen was analyzed by the START device (Diagnóstica Stago, Asnieres, France) with LABTEST commercial kits (Lagoa Santa, Minas Gerais, Brazil). Glutamic oxaloacetic transaminase (GOT) and glutamic pyruvic transaminase (GPT) serum were measured by the IFCC method (HITACHI $917^{\circledR}$ apparatus, Roche Diagnostics, Florida, USA). The ultrasensitive Creactive protein (CRP) was assessed by Nephelometry (Nephelometer Beckman Coulter, Immage model with laboratory reagents CCRP Immage, 
Fullerton, CA, USA). Lactate was evaluated through tapes (Roche Diagnostics GmbH, Mannheim, Germany) and analyzed by the Accutrend PLUS device (Roche, Schweiz, Switzerland).

The erythrogram and leukogram tests were made in automatized processor ABX micros 60 (Horiba Diagnostica, Curitiba, Brazil) based on the principles of impedance and photometry. In addition, optical microscope analyzes (Olympus, CX41, Center Valley, PA, USA) were performed for identification and differential quantification of leukocytes through blood smears, which were previously prepared with hematological staining (May-Grünwald Giemsa). For quantification of the hematological variables the samples were counted twice and the values were expressed by the mean of the measurements (differences greater than $10 \%$ were repeated).

$\mathrm{Mg}^{2+}$ and $\mathrm{Ca}^{2+}$ were evaluated by commercial kits LAB TEST (Lagoa Santa, MG, Brazil) and analyzed by LAB MAX $240^{\circ}$ (Tokio, Japan). Serum $\mathrm{Na}^{+}$ and $\mathrm{K}^{+}$were dosed by the automated selective electrode method (ROCHE 9180 Electrolyte Analyzer, AVL Medical Instruments, Switzerland, Austria).

\section{Statistical analysis}

The data are expressed as mean and standard deviation (SD), and variations between groups are presented as mean difference (MD) and 95\% confidence interval (CI 95\%). The distribution of the variables was tested with the Kolmogorov-Smirnov normality test. Variables with two measurements were compared by Student's paired t-test. Variables with more than two measurements were analyzed by One-way ANOVA for repeated measures or by Friedman test, both followed by the Bonferroni post hoc test. Pearson's correlation ( $r$ ) was used. The level of statistical significance was considered 5\% ( $p<0.05)$.

\section{RESULTADOS}

The volunteers were $26.9( \pm 4.4)$ years old and had $26.1( \pm 2.9) \mathrm{kg} / \mathrm{m}^{2}$. The mean muscle strength of the volunteers assessed by the 10RM test for leg press was $121( \pm 23) \mathrm{kg}$, squat $73( \pm 16) \mathrm{kg}$ and knee extension 56 $( \pm 12) \mathrm{kg}$. Lipid profile, glucose, uric acid, urea, TGO and TGP were within the reference values for the sample. DOMS evaluated $24 \mathrm{~h}$ after RE presented an average intensity of $6.2( \pm 1.7)$ points (data presented in Table 1). Lactate (baseline: $1.8 \pm 0.5 \mathrm{mmol} / \mathrm{L}$ ) increased approximately six-fold after (10.5 $\pm 1.25 \mathrm{mmol} / \mathrm{L}$ ) RE (MD: $8.795 \% \mathrm{Cl}: 8.1$ to 9, $4 \mathrm{mmol} / \mathrm{L} ; \mathrm{p}<0.001)$. During the study, all volunteers had muscle fatigue, but no musculoskeletal injuries or adverse effects on exercise were observed or reported. (Table 1)

The results of erythrogram, leukogram and inflammatory markers are within normal limits and are presented in table 2. (Table 2)

Table 1. Anthropometric, laboratory and DOMS characteristics.

\begin{tabular}{c|c|c}
\hline Variables & Mean & SD \\
\hline Age $(\mathrm{y})$ & 26,9 & 4,4 \\
\hline Weight $(\mathrm{kg})$ & 78,8 & 8,14 \\
\hline Height $(\mathrm{m})$ & 1,74 & 0,06 \\
\hline BMI $\left(\mathrm{kg} / \mathrm{m}^{2}\right)$ & 26,1 & 2,9 \\
\hline Total cholesterol $(\mathrm{mg} / \mathrm{dL})$ & 154,2 & 29,1 \\
\hline HDL $(\mathrm{mg} / \mathrm{dL})$ & 32,9 & 5,8 \\
\hline LDL $(\mathrm{mg} / \mathrm{dL})$ & 99,3 & 27,7 \\
\hline Triglycerides $(\mathrm{mg} / \mathrm{dL})$ & 113,7 & 62,7 \\
\hline Glucose $(\mathrm{mg} / \mathrm{dL})$ & 83,5 & 26,5 \\
\hline Uric acid $(\mathrm{mg} / \mathrm{dL})$ & 7,7 & 7,9 \\
\hline Urea $(\mathrm{mg} / \mathrm{dL})$ & 28,9 & 6,7 \\
\hline GOT $(\mathrm{U} / \mathrm{L})$ & 33,2 & 13,2 \\
\hline GPT $(\mathrm{U} / \mathrm{L})$ & 31,2 & 10,3 \\
\hline DOMS 24h $(0-10$ points) & 6,2 & 1,7 \\
\hline
\end{tabular}

Data presented as mean and standard deviation (SD). BMI: body mass index, HDL: high density lipoprotein VLDL: very low density lipoprotein; LDL: low density lipoprotein; GOT: glutamic-oxaloacetic transaminase: GPT: glumatic-pyruvic transaminase; DOMS: delayed onset muscle soreness.
Table 2. Erythrogram, leukogram and inflammatory markers.

\begin{tabular}{c|c|c}
\hline Variables & Mean & SD \\
\hline Hematocrit $(\%)$ & 48 & 2,2 \\
\hline Platelets $\left(\times 10^{3} / \mathrm{mm}^{3}\right)$ & 250 & 31,1 \\
\hline Erythrocytes $\left(\times 10^{5} / \mathrm{mm}^{3}\right)$ & 5,21 & 0,31 \\
\hline Total leukocytes $\left(\times 10^{3} / \mathrm{mm}^{3}\right)$ & 6875 & 876 \\
\hline Young neutrophils $\left(\times 10^{3} / \mathrm{mm}^{3}\right)$ & 72 & 13 \\
\hline Segmented neutrophils $\left(\times 10^{3} / \mathrm{mm}^{3}\right)$ & 3738 & 730 \\
\hline Eosinophils $\left(\times 10^{3} / \mathrm{mm}^{3}\right)$ & 123 & 70 \\
\hline Monocytes $\left(\times 10^{3} / \mathrm{mm}^{3}\right)$ & 289 & 72 \\
\hline Lymphocytes $\left(\times 10^{3} / \mathrm{mm}^{3}\right)$ & 2616 & 484 \\
\hline Fibrinogen $\left(\mathrm{mg} / \mathrm{dL}^{3}\right.$ & 293 & 85 \\
\hline CRP $(\mathrm{mg} / \mathrm{dL})$ & 0,96 & 0,68 \\
\hline
\end{tabular}

Data presented as mean and standard deviation (SD). CRP: C-reactive protein.

Immediately after $\mathrm{RE}, \mathrm{Na}^{+}$plasma concentrations increased by $1.4 \mathrm{mEq} / \mathrm{L}(95 \% \mathrm{Cl}: 0.2$ to $2.6 \mathrm{mEq} / \mathrm{L} ; \mathrm{p}<0.001)$ and $30 \mathrm{~min}$ after RE these values decreased by $1.3 \mathrm{mEq} / \mathrm{L}(95 \% \mathrm{Cl}:-2.5$ to $-0.1 \mathrm{mEq} / \mathrm{L} ; \mathrm{p}<0.001)$ in relation to the concentrations obtained immediately after exercise completion, returning close to baseline $(139.5 \mathrm{mEq} / \mathrm{L})$ after exercise. Plasma $\mathrm{K}^{+}$ concentrations increased 30 min after RE $(p<0.001)$, with these values being respectively 6\% (MD: $0.2795 \% \mathrm{Cl}: 0.1$ to $0.45 \mathrm{mEq} / \mathrm{L})$ higher than baseline and 9\% (MD: $0.4195 \% \mathrm{Cl}: 0.23$ to $0.59 \mathrm{mEq} / \mathrm{L}$ ) compared to the measurement taken immediately after the end of RE. Plasma $\mathrm{Ca}^{2+}$ and $\mathrm{Mg}^{2+}$ concentrations did not change throughout the study (Figure 1).

The baseline $\mathrm{Na}^{+}$and $\mathrm{K}^{+}$plasma values did not correlate $(r=-0.26$ 95\% Cl: -0.63 to $0.21 ; p=0.276$ ). However, immediately after RE these measurements showed an inversely proportional correlation $(r=-0.51$; 95\% Cl: -0.09 to $-0.77 ; p=0.021)$, where $\mathrm{Na}^{+}$increased and $\mathrm{K}^{+}$decreased. These results were repeated 30 min after RE ( $r=-0.44 ; 95 \% \mathrm{Cl}:-0.01$ to $-0.74 ; \mathrm{p}=0.049$ ), but, inversely, as when $\mathrm{Na}^{+}$decreased $\mathrm{K}^{+}$increased. $\mathrm{Na}^{+}$ plasma concentrations immediately after RE correlated inversely with the DOMS ( $r=-0.52 ; 95 \% \mathrm{Cl}: 0.10$ to $0.78 ; p=0.018$ ). (Figure 2)

\section{DISCUSSION}

Resistance exercise, performed at high intensity by untrained healthy volunteers, alters $\mathrm{Na}^{+}$and $\mathrm{K}^{+}$plasma concentrations, where immediately after exercise $\mathrm{Na}^{+}$increases and later returns to baseline concentrations. On the other hand, the $\mathrm{K}^{+}$increases $30 \mathrm{~min}$ after the end of the exercises. These electrolyte changes $\left(\mathrm{Na}^{+}\right.$and $\left.\mathrm{K}^{+}\right)$correlate inversely with each other and $\mathrm{Na}^{+}$plasma concentrations immediately after exercise also correlate inversely with the DOMS evaluated $24 \mathrm{~h}$ after RE.

In the present study, $\mathrm{Na}^{+}$increased immediately after RE (0 min) and then decreased (30 min). These changes are within fasting reference values $^{13}$ and are associated with changes in hemoconcentration ${ }^{6}$ and osmolarity. ${ }^{19}$ Hemoconcentration occurs immediately after the end of RE and is due to the lack of hydration during the exercises, ${ }^{6}$ which resulted in the $\mathrm{Na}^{+}$increase observed ( $0 \mathrm{~min}$ ) in the present study. Boone et al. ${ }^{19}$ evaluated trained volunteers undergoing the high-intensity RE session and observed that $\mathrm{Na}^{+}$and osmolarity did not change immediately after exercise. ${ }^{19}$ This difference $(0 \mathrm{~min})$ is due to the free access to water intake during exercise, and to the fact that the sample was composed of trained individuals. ${ }^{19}$ Corroborating to our results, Boone et al. ${ }^{19}$ demonstrated a reduction in $\mathrm{Na}^{+}$and osmolarity 30 min after the end of the RE session.

The RE performed at high intensity increased the plasma concentrations of $\mathrm{K}^{+} 30 \mathrm{~min}$ after the end of the exercises. $\mathrm{K}^{+}$concentration is regulated by the kidneys, acts on membrane potential ${ }^{20}$ and its levels have changed within fasting normal parameters. ${ }^{13,18} \mathrm{~K}^{+}$results found in the present study are in agreement with a previous study that evaluated trained subjects undergoing high intensity $\mathrm{RE}^{19}{ }^{19}$ where $\mathrm{K}^{+}$was already increased immediately after exercise and remained for $1 \mathrm{~h}$ above baseline 

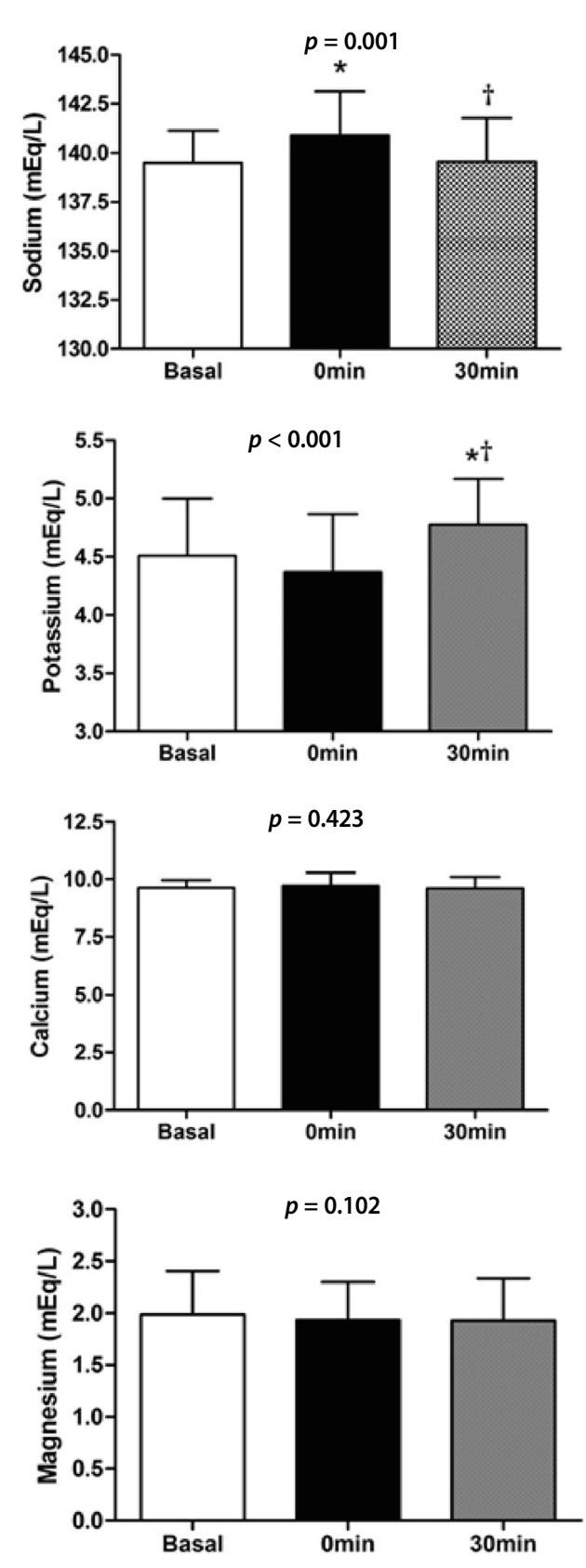

${ }^{*} p<0,05$ vs Basal; $+p<0,05$ vs 0min

Figure 1. Electrolyte changes.

concentrations. ${ }^{19}$ In the present study, no $\mathrm{K}^{+}$changes were observed immediately ( 0 min) after RE and this is due to the free access to water intake by the volunteers after the exercises. Fatigue symptoms are felt after a $2 \%$ depletion of $\mathrm{K}^{+} .{ }^{18} \mathrm{It}$ is noteworthy that in the present study the volunteers worked at full load and presented fatigue at the end of the RE, but without other adverse effects.

The results of this research demonstrate that changes in $\mathrm{Na}^{+}$and $\mathrm{K}^{+}$plasma concentrations correlated inversely ( 0 min and $30 \mathrm{~min}$ ) after RE. Plasma concentrations of these electrolytes are dependent on the activity of the enzyme $\mathrm{Na}^{+} / \mathrm{K}^{+}$-ATPase, ${ }^{21}$ as it stabilizes the concentrations of these electrolytes during exercise. ${ }^{22}$ This enzyme acts directly on muscle function because it modulates the contractility and excitability of the skeletal muscle and also contributes to its remodeling. ${ }^{21,22} \mathrm{~A}$ recent research has shown that there are two isoforms of this enzyme, where a1 isoform responds most to resistance exercise and a2 to aerobic exercise. ${ }^{21}$
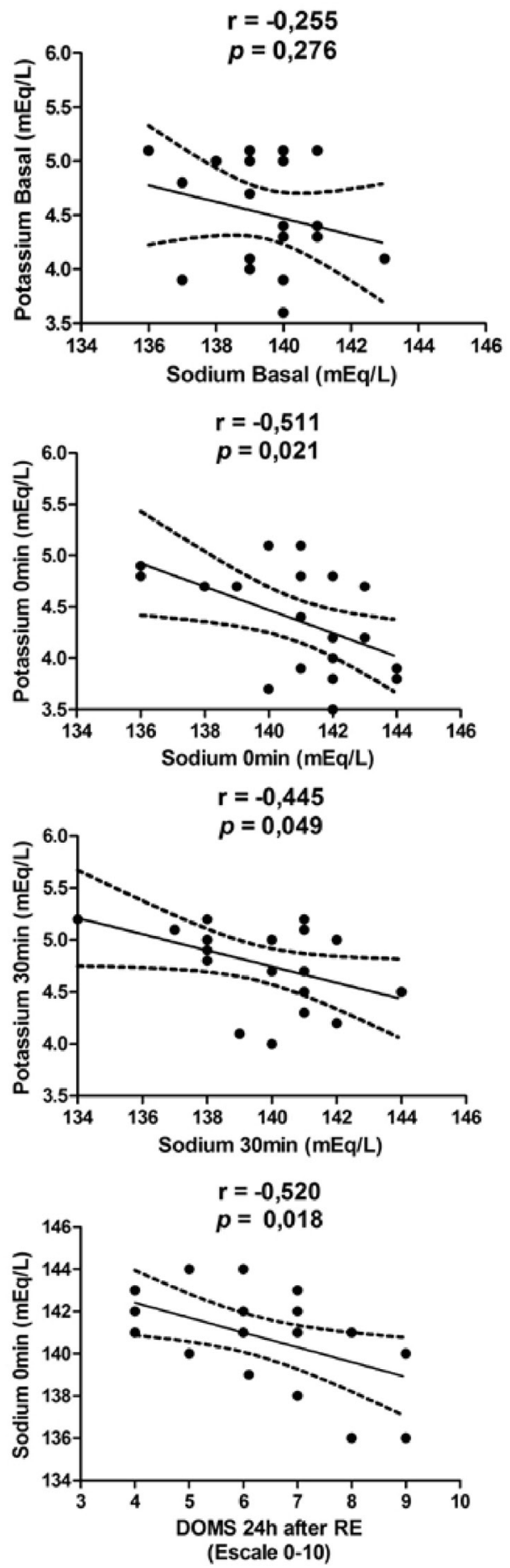

r: Pearson

Figure 2. Correlations between electrolytes and DOMS

We believe that the decreases in $\mathrm{Na}^{+}$plasma concentrations and, in particular, the increase in $\mathrm{K}^{+}$found 30 min after $\mathrm{RE}$ in the present study, are due to the lower $\mathrm{Na}^{+} / \mathrm{K}^{+}$-ATPase activity, ${ }^{22}$ especially the $\mathrm{a} 1$ isoform. ${ }^{21}$

In the present study, the volunteers underwent maximal load, which would stimulate excessive post-exercise oxygen consumption (EPOC). EPOC interferes with $\mathrm{Na}^{+} / \mathrm{K}^{+}$-ATPase activity because it acts on ATP/CP resynthesis, ion redistribution, lactate removal, tissue damage restoration, heart rate and body temperature. ${ }^{23}$ Increased metabolism reduces the enzyme's ability to restore plasma electrolyte concentrations ${ }^{22}$ and untrained individuals are more vulnerable to these changes..$^{13}$ EPOC is associated with DOMS after submaximal running. ${ }^{24}$ These changes are 
dependent on the variables (volume, intensity) of the $\mathrm{RE}_{1}{ }^{19}$ on the size of the muscle mass involved in the exercises ${ }^{25}$ and on the individual's level of training. ${ }^{13}$

The present study demonstrates that DOMS correlates with the lowest plasma $\mathrm{Na}^{+}$concentrations evaluated immediately after $\mathrm{RE}$. $\mathrm{Na}^{+}$ loss combined with dehydration can lead to cramps, ${ }^{13,14}$ which was not reported by volunteers in the present study. We believe that dehydration did not occur and electrolyte changes are within fasting reference parameters, ${ }^{13}$ but the results suggest that hydration with isotonic substances is more effective in reducing DOMS. The lack of measurements of osmolarity, EPOC and activity and / or expression of $\mathrm{Na}^{+} / \mathrm{K}^{+}$-ATPase isoforms ( $a 1$ and $a 2$ ) is a limitation of the present study.

\section{CONCLUSIONS}

ER performed at high intensity by untrained healthy volunteers alter $\mathrm{Na}^{+}$and $\mathrm{K}^{+}$plasma concentrations and these changes are interrelated. $\mathrm{Na}^{+}$concentrations immediately after exercise are related to DOMS, suggesting that these individuals are more likely to lose this electrolyte, which is partly related to muscle pain after RE. Preventive measures, such as the use of isotonic drinks during RE sessions, must be tested, as they can alleviate these changes and musculoskeletal discomfort after these exercises in untrained healthy volunteers.

\section{ACKNOWLEDGMENTS}

To the Institute of Biological Sciences - FURG, to the Laboratory of Clinical Analysis of the Associação de Caridade Santa Casa do Rio Grande Hospital, and to the Rouget Perez Laboratory in Pelotas, which collaborated in the analysis and data processing. The present study had support from the National Council of Technological and Scientific Development (Conselho Nacional de Desenvolvimento Científico e Tecnológico - CNPq) and the Research Support Foundation from Rio Grande do Sul State (Fundação de Amparo à Pesquisa do Estado do Rio Grande do Sul - FAPERGS), with support from the Higher Education Personnel Improvement Coordination - Brazil (CAPES) - Financing Code 001.

All authors declare no potential conflict of interest related to this article

AUTHORS' CONTRIBUTIONS: Each author made significant individual contributions to this manuscript.. AOT, EB, BCC: collection and analyses of the data; KSF, GOP and AMVS: performed the data interpretation and writing of the manuscript; FSP and LUS*: were responsible for the preparation of the project, and performed the statistical analyses. All the authors revised and approved the final version of the manuscript.

\section{REFERENCE}

1. Morton RW, Murphy KT, McKellar SR, Schoenfeld BJ, Henselmans M, Helms E, et al. A systematic review, meta-analysis and meta-regression of the effect of protein supplementation on resistance traininginduced gains in muscle mass and strength in healthy adults. Br J Sports Med. 2018;52(6):376-84.

2. Silva Jr. AJ, Souza MV, Tomaz LM, Bertucci DR, Souza GS, Vanevazzi GH, et al. Estudo do comportamento cortisol, GH e insulina após uma sessão de exercício resistido agudo. Rev Bras Med do Esporte. 2014 [acesso em: 2017/03/24];20(1):21-5. Disponível em: http://www.scielo.br/scielo. phpsp?script=sci_arttext\&pid=\$1517-86922014000100021\&lng=pt\&tlng=pt

3. American College of Sports Medicine position stand. Progression models in resistance training for healthy adults. Med Sci Sport Exerc. 2009;41(3):687-708.

4. Missau E, Teixeira AO, Franco OS, Martins CN, Paulitsch FS, Peres W, et al. Cold water immersion in the inflammatory response after resistant exercises. Rev Bras Med. 2018;24(5):372-6

5. Teixeira AO, Paulitsch FS, Umpierre MM, Moraes MB, Rosa CE, Signori LU. Resposta inflamatória após sessão de exercícios resistidos em voluntários destreinados. Acta Sci Heal Sci. 2014;37(1):31-9.

6. Teixeira AO, Franco OS, Borges MM, Martins CN, Guerreiro LF, Rosa CE da, et al. The importance of adjustments for changes in plasma volume in the interpretation of hematological and inflammatory responses after resistance exercise. J Exerc Physiol. 2014;17(4):72-83.

7. Ingalls $C P$, Wenke JC, Nofal T, Armstrong RB. Adaptation to lengthening contraction-induced injury in mouse muscle. J Appl Physiol (1985). 2004;97(3):1067-76.

8. Bessa AL, Oliveira VN, Agostini GG, Oliveira RJ, Oliveira AC, White GE, et al. Exercise intensity and recovery: biomarkers of injury, inflammation, and oxidative stress. J Strength Cond Res. 2016 [acesso em: 2018/03/16];30(2):311-9. Disponível em: http://www.ncbi.nlm.nih.gov/pubmed/23604000

9. Hoekstra SP, Bishop NC, Leicht CA. Can intervals enhance the inflammatory response and enjoyment in upper-body exercise? Eur J Appl Physiol. 2017;117(6):1155-63.

10. Cruzat VF, Rogero MM, Borges MC, Tirapegui J. Current aspects about oxidative stress, physical exercise and supplementation. Rev Bras Med Esporte. 2007;13(5):304-10.

11. Glasgow PD, Ferris R, Bleakley CM. Cold water immersion in the management of delayed-onset muscle soreness: Is dose important? A randomised controlled trial. Phys Ther Sport. 2014 [acesso em: 2018/02/08];15(4):228-33. Disponível em: http://dx.doi.org/10.1016/j.ptsp.2014.01.002

12. Paulsen G, Mikkelsen UR, Raastad T, Peake JM. Leucocytes, cytokines and satellite cells: what role do they play in muscle damage and regeneration following eccentric exercise? Exerc Immunol Rev. 2012 [acesso em 2018/08/08];18:42-97. Disponível em: http://www.ncbi.nlm.nih.gov/pubmed/22876722

13. Évora PR, Reis CL, Ferez MA, Conte DA, Garcia LV. Distúrbios do equilíbrio hidroeletrolítico e do equilíbrio acidobásico - Uma revisão prática. Med Ribeirão Preto. 1999;32(4):451-69.
14. Giuriato G, Pedrinolla A, Schena F, Venturelli M. Muscle cramps: a comparison of the two-leading hypothesis. J Electromyogr Kinesiol. 2018;41:89-95.

15. Rasmussen AQ, Jørgensen NR, Schwarz P. Identification and functional characterization of a novel mutation in the human calcium-sensing receptor that $\mathrm{Co}$-segregates with autosomal-dominant hypocalcemia. Front Endocrinol (Lausanne). 2018;9:200.

16. Minuzzi LG, Teixeira AM, Carvalho HM, Costa RJ Da, Rama L. Daily hematologic assessment during a 230km multistage ultramarathon. Rev Bras Med do Esporte. 2018 [acesso em 2018/04/21];24(3):206-11. Disponível em: http://www.scielo.br/scielo.php?script=sci_arttext\&pid=S1517-86922018000300206\&ln $\mathrm{g}=$ en\&tlng=en

17. Machado AF, Evanglista AL, Miranda JM, Teixeira CV, Leite GS, Rica RL, et al. Sweat rate measurements after high intensity interval training using body weight. Rev Bras Med do Esporte. 2018;24(3):197-201.

18. Mara LS, Lemos R, Brochi L, Rohlfs IC, Carvalho T. Alteraçōes hidroeletrolíticas agudas ocorridas no Triatlon Ironman Brasil. Rev Bras Med Esporte. 2007;13(6):397-401.

19. Boone CH, Hoffman JR, Gonzales AM, Jajtner AR, Townsend JR, Baker KM, et al. Changes in plasma aldosterone and electrolytes following high-volume and high-intensity resistance exercise protocols in trained men. J Strength Cond Res. 2016;30(7):1917-23.

20. Viana LA, Burgos MG, Silva RA. Refeeding syndrome: clinical and nutritional relevance. Arq Bras Ci Dig. 2012;25(1):56-9.

21. Kutz LC, Mukherji ST, Wang X, Bryant A, Larre I, Heiny JA, et al. Isoform-specific role of Na/K-ATPase a1 in skeletal muscle. Am J Physiol Endocrinol Metab. 2018;314(2):620-9.

22. Mckenna MJ, Bangsbo J, Renaud JM. Muscle K+, Na+, and Cl- disturbances and $\mathrm{Na}+-\mathrm{K}+$ pump inactivation: implications for fatigue. J Appl Physiol (1985). 2008;104(1):288-95.

23. Foureaux G, Pinto KM, Dâmaso A. Efeito do consumo excessivo de oxigênio após exercício e da taxa metabólica de repouso no gasto energético. Rev Bras Med Esporte. 2006 [acesso em 2018/03/01]; 12(6):3938. Disponivel em: http://www.scielo.br/scielo.php?script=sci_arttext\&pid=\$1517-86922006000600018\&ln $\mathrm{g}=\mathrm{pt \& n}$ rm=iso\&tlng=pt

24. Burt DG, Lamb K, Nicholas C, Twist C. Effects of exercise-induced muscle damage on resting metabolic rate, sub-maximal running and post-exercise oxygen consumption. Eur J Sport Sci. 2014;14(4):337-44

25. Farinatti P, Castinheiras Neto AG, Amorim PRS. Oxygen consumption and substrate utilization during and after resistance exercises performed with different muscle mass. Int J Exerc Sci. 2016 [acesso em 2017/12/03];9(1):77-88. Disponível em: http://search.ebscohost.com/login.aspx?direct=true\& $\mathrm{db}=\mathrm{s} 3 \mathrm{~h} \& \mathrm{AN}=112420135 \&$ lang $=$ pt-br\&site=ehost-live. 